\title{
The impact of COVID-19 pandemic on divorce rates among Indonesian Muslim societies
}

\author{
Isnawati Rais
}

UIN Syarif Hidayatullah, Jakarta

E-mail: isnawati.rais@uinjkt.ac.id

DOI:10.18326/ijims.v11i2.271-297

\begin{abstract}
This study aims to look at the impact of the COVID-19 pandemic on divorce rates in Indonesia. Few months after the outbreak, the media reported the increasing divorce rates. Some authorities and researchers have taken this information for granted; therefore, their responses can be misleading. This socio-legal study confronts the media reports with the statistical data on divorce case numbers received by the Religious (Islamic) Courts and the Religious Courts judges' explanation about the issue. This study finds out that the one-year period (2020) of the COVID-19 pandemic has not influenced the rates of divorce cases submitted to the court. Social mobility restrictions and the inadequate use of the E-Court facility to enhance courts' performance are among the causes of the crowding of divorce applicants. This implies that the current COVID-19 pandemic has little impact on divorce dynamics despite its significant influence on households' economic instability and the increasing of domestic violence cases. With a more careful response to the media report, the authorities will be able to address the real issues faced by many households and the judiciary.
\end{abstract}


Penelitian ini bertujuan untuk melihat dampak pandemi COVID-19 terhadap angka perceraian di Indonesia. Beberapa bulan setelah wabah, media melaporkan peningkatan angka perceraian. Beberapa otoritas dan peneliti telah menerima informasi ini begitu saja; oleh karena itu, tanggapan mereka dapat menyesatkan. Kajian sosio-legal ini menghadapkan pemberitaan media dengan data statistik jumlah perkara perceraian yang diterima oleh Pengadilan Agama dan penjelasan hakim Pengadilan Agama tentang masalah tersebut. Studi ini menemukan bahwa periode satu tahun (2020) dari pandemi COVID-19 tidak mempengaruhi tingkat kasus perceraian yang diajukan ke pengadilan. Keterbatasan mobilitas sosial dan penggunaan fasilitas E-Court yang tidak memadai untuk meningkatkan kinerja pengadilan menjadi salah satu penyebab ramainya pemohon cerai. Artinya, pandemi COVID-19 saat ini tidak banyak berdampak pada dinamika perceraian meskipun berpengaruh signifikan terhadap ketidakstabilan ekonomi rumah tangga dan meningkatnya kasus kekerasan dalam rumah tangga. Dengan tanggapan yang lebih hati-hati terhadap laporan media, pihak berwenang akan dapat mengatasi masalah nyata yang dihadapi oleh banyak rumah tangga dan peradilan.

Keywords: Divorce; Islamic courts; Religious courts, COVID-19; Pandemic

\section{Introduction}

At the end of 2019, precisely December 8, the world was shocked by an outbreak that initially hit Wuhan, China. In Indonesia, the first case of COVID-19 was confirmed on March 2, 2020. Data on August 14, 2021 showed that there had been 3.89 million cases in Indonesia, with 120 thousand deaths. ${ }^{1}$ As for global numbers, there have been 208 million cases, with 4.37 million deaths. ${ }^{2}$ The numbers are still counting. The disease is easily transmitted through droplets by close contact with the virus carriers. Mobility limitation, social distancing, area lockdown or

\footnotetext{
1"Indonesia: WHO Coronavirus Disease (COVID-19) Dashboard with Vaccination Data," accessed August 19, 2021, https://COVID19.who.int.

2"WHO Coronavirus (COVID-19) Dashboard," accessed August 19, 2021, https:// COVID19.who.int.
} 
quarantine, and isolation become the only choices to prevent the disease from spreading.

In Indonesia, the government has determined the social mobility limitation by the Large Scale Social Restriction (PSBB). However, this strict limitation is not a very easy choice, as the socio-economic impact of this policy was hard. In the following days, the government loosened the regulations using Micro Scale Activity Restriction (PPKM). This is to enable people to do economic activities and access services. Educational services, however, has temporarily been closed since March 2020. The pandemic has posed hardship in various sectors. Unemployment is among them. This, in turn, leads to social instability.

Surveys by UNICEF and other institutions have revealed that the pandemic has a significant negative impact on household finance. Most of the households (74.3\%) in the survey experienced a decrease in their income several months after the pandemic began. This leads to economic distress within families, which in many cases, leading to tensions. Moreover, parents need to juggle between work and supporting their children's schooling with the homeschooling policy. This is most likely to be in women's care, as admitted by $71.5 \%$ of the households in the survey. ${ }^{3}$ At some point, family resilience is at stake.

In August 2020, Indonesians were surprised by the spreading of a video showing a long queue of people in the Religious Court of Bandung Regency, intending to file a divorce. ${ }^{4}$ The media helped spread the issue. Even more, Indonesian scholars began to study this phenomenon by

${ }^{3}$ UNICEF et al., Analysis of the Social and Economic Impacts of COVID-19 on Households and Strategic Policy Recommendation for Indonesia, Jakarta: United Nation Children's Fund, 2021, https://www.id.undp.org/content/indonesia/en/home/library/HH-SocioEconomic-Report.html.

${ }^{4}$ Muhammad Iqbal, "Viral Antrean Mengular Pasutri Mau Cerai di PA Bandung, Apa Benar?," detiknews, August 24, 2020, https://news.detik.com/berita-jawa-barat/d-5144552/ viral-antrean-mengular-pasutri-mau-cerai-di-pa-bandung-apa-benar. 
asking various questions as to why this could have happened. Religious figures, psychologists, and even the Religious Court judges were used as references. However, they barely explain what happened, and is the information about the increase in the divorce rate valid? There is still a need to carefully examine and verify this phenomenon to avoid misjudgment and misinterpretation.

This paper aims to critically investigate the impact of the pandemic on the divorce rates in Indonesia. Has the pandemic led to the increase in divorce rates as reported by the media? Until this paper is written, the COVID-19 pandemic has been going on for two years. This provides an opportunity to look at the divorce rates from the early beginning of the pandemic in 2019 to 2020. This research will explain what has happened and reveal the vulnerable issues faced by the state and society. As this is a socio-legal inquiry, this knowledge is essential for the state dealing with the actual family issues in society.

\section{Pandemic and its impact on family issues}

The COVID-19 Pandemic has significantly impacted various aspects of human life, not only health issues. Psychological and economic impacts are among sectors influenced by the pandemic. ${ }^{5}$ This, in turn, affects not only individual but also family life. Recent studies have discussed family issues concerning the pandemic, how it leads to family problems, and how families cope.

The pandemic has forced many governments to impose a strict lockdown policy to prevent extensive humans' mobility and prevent the disease from

${ }^{5}$ Dunya Ahmed, Mohamed Buheji, and S. Merza Fardan, "Re-Emphasising the Future Family Role in 'Care Economy' as a Result of COVID-19 Pandemic Spillovers", American Journal of Economics, Volume 10, Number 6 (2020), 332-38; Paschal Chiedozie Amakiri et al., "Psychological Effect of Pandemic COVID-19 on Families of Health Care Professionals", British Journal of Psychology Research, Volume 8, Number 2 (2020), 1-7. 
spreading. In some cases, such policies bring challenges to people from economic difficulties and family and relationship distress. Economic difficulties as the impact of the pandemic have led to family tensions. ${ }^{6}$ This may not directly occur; a gradual process is often needed to make a family finally faces difficulties. ${ }^{7}$ Among the difficulty are public activity restrictions and social isolation that lead to double burdens experienced, especially by parents. ${ }^{8}$ They need to work from home and, at the same time, act as teachers for their children. ${ }^{9}$

Various studies revealed increasing domestic violence cases during the COVID-19 pandemic in many countries, including China, Brazil, Italy, the United States of America, and the United Kingdom. ${ }^{10}$ The social structures impacted by the pandemic can lead to domestic violence, which includes poverty, unemployment, homelessness, isolation, etc. ${ }^{11}$ This commonly occurs during the hardship caused by a natural disaster. ${ }^{12}$ The psychological impacts that can emerge are anger, confusion, stress, and others. ${ }^{13}$ In Indonesia, KOMNAS Perempuan (National Commission

\footnotetext{
${ }^{6}$ Qisti Aufa Afifah, "Analysis of the Impact of the COVID-19 Pandemic on Family Harmony: Case Studies on Family with and without People with Special Needs", Indonesian Journal of Community and Special Needs Education, Volume 1, Number 2 (2021), 87-92; Ahmed, Buheji, and Fardan, "Re-Emphasising the Future"...

${ }^{7}$ Qisti Aufa Afifah, "Analysis of the Impact of the COVID-19...

${ }^{8}$ UNICEF et al., "Analysis of the Social and Economic Impacts...

${ }^{9}$ UNICEF et al., "Analysis of the Social and Economic Impacts...

${ }^{10}$ Kathryn L. Humphreys, Myo Thwin Myint, and Charles H. Zeanah, "Increased Risk for Family Violence During the COVID-19 Pandemic", Pediatrics, Volume 146, Number 1 (2020), https://doi.org/10.1542/peds.2020-0982; Andrew M. Campbell, "An Increasing Risk of Family Violence during the COVID-19 Pandemic: Strengthening Community Collaborations to Save Lives", Forensic Science International: Reports, Volume 2 (2020): 100089, https://doi. org/10.1016/j.fsir.2020.100089; Hongwei Zhang, "The Influence of the Ongoing COVID-19 Pandemic on Family Violence in China", Journal of Family Violence (2020), 1-11.

${ }^{11}$ Andrew M. Campbell, "An Increasing Risk of Family Violence during the COVID-19 Pandemic...

${ }^{12}$ Hongwei Zhang, "The Influence of the Ongoing COVID-19 Pandemic...

${ }^{13}$ Humphreys, Myint, and Zeanah, "Increased Risk for Family Violence During the COVID-19...
} 
on Violence Against Women) reveals that the pandemic has increased domestic violence cases. KOMNAS Perempuan received 2,389 domestic violence cases in 2020. This number is 60\% higher than it was in 2019, which amounted to 1,413 cases. The highest cases were domestic violence involving wives as victims, with 6,480 cases or $79 \%$ of the total cases. ${ }^{14}$

Studies have been conducted to see the impact of the COVID-19 pandemic on divorce rates. However, studies by Manning and Payne in the U.S.A. and Fallesen in Denmark show the decline in divorce rates during the pandemic. The authors explain that, up to that, the pandemic has not led to the increase of the divorce rates. In those two countries, there has been a trend of decreasing people's interest to marry. With the increase of risks in family resilience, it is reasonable if the issues also lead to a separation.

As a consequence, the possibility of divorce has also declined. ${ }^{15}$ Moreover, in some cases, the pandemic is often considered the cause of increasing divorce rates. However, the impact of the pandemic may not consistently be negative. For example, Ahmed et al. found that the pandemic strengthens family bonding, especially with extended families. ${ }^{16}$

Some studies have also been conducted in Indonesia concerning the impact of the COVID-19 pandemic on divorce rates. Studies by Ramadhani and Nurwati, and Ulfa and Bunaiya are examples. ${ }^{17}$ These two studies,

\footnotetext{
${ }^{14}$ Komnas Perempuan, "Siaran Pers," Komnas Perempuan | Komisi Nasional Anti Kekerasan Terhadap Perempuan, March 5, 2021, https://komnasperempuan.go.id/siaranpers-detail/catahu-2020-komnas-perempuan-lembar-fakta-dan-poin-kunci-5-maret-2021.

${ }^{15}$ Peter Fallesen, "Decline in Rate of Divorce and Separation Filings in Denmark in 2020 Compared with Previous Years”, Socius, Volume 7 (2021), 23780231211009990; Manning and Payne, "Marriage and Divorce Decline During the COVID-19 Pandemic...

${ }^{16}$ Dunya Ahmed, Mohamed Buheji, and S. Merza Fardan, "Re-Emphasising the Future Family Role in 'Care Economy' as a Result of COVID-19 Pandemic Spillovers", American Journal of Economics, Volume 10, Number 6 (2020), 332-38.

${ }^{17}$ Salsabila Rizky Ramadhani and Nunung Nurwati, "Dampak Pandemi COVID-19 Terhadap Angka Perceraian”, Jurnal Penelitian dan Pengabdian Kepada Masyarakat, Volume 2, Number 1 (2021), 88-94, https://doi.org/10.24198/jppm.v2i1.33441; Mawaddatul Ulfa and
} 
however, seem to take the news on increasing divorce rates for granted. Both focus on studying the factors leading to the increasing rates of divorce, which are economic problems, early age marriages, and frequent quarrels. What needs to be criticized is that all these factors are common causes of divorce even during the average period, as they are presented in the annual report of the Supreme Court of Indonesia. Therefore, there is a need for a more critical and thorough study supported by more comprehensive data and evidence to explain the impact of the COVID-19 pandemic on divorce rates. The study taking place in Indonesia can contribute to a broader discussion explaining the issue.

\section{Divorce rules in Indonesia}

In Indonesia, marriage and divorce are regulated by the Marriage Law of 1974. For Muslims, the state adds the Compilation of Islamic Law. Referring to these regulations, marriage and divorce should be registered and recorded by the state, which in turn determines the Office of Religious Affairs (Kantor Urusan Agama/K.U.A.) to document Muslims' marriages and the Religious (Islamic) Courts to pronounce a divorce. This is mentioned in Article 115 of the Compilation of Islamic Law and Article 39 (1) of the Marriage Law of 1974. The regulations aim to protect every involved party's right after the divorce, especially women and children. With this procedure, marriage and divorce certificates can be obtained and used to claim the respective rights. However, with the state recognizing Islamic law, unregistered marriages and divorces are still tolerated. They are still considered lawful even though the involved parties cannot demand the rights without the legal documents.

With the ongoing legal reform in Indonesia, the Religious Courts play a

Mahlil Bunaiya, "The Effect of COVID-19 on the High Divorce Rate in Kabupaten Lima Puluh Kota”, HUNAFA: Jurnal Studia Islamika, Volume 18, Number 1 (2021), 114-37, https:// doi.org/10.24239/jsi.v18i1.617.114-137. 
significant role in providing better access to justice for its seeker. Sumner and Lindsey argue that the Religious Courts have successfully delivered justice for the marginalized groups, such as women, children, and the disadvantaged. ${ }^{18}$ During the Pandemic, such a role becomes increasingly significant, considering that many families have been vulnerable. ${ }^{19}$ People's legal awareness regarding the need for an official legal process for divorce has made them continue to come to court seeking legal certainty of their marital status.

\section{Divorce trends amidst the COVID-19 Pandemic}

\section{Questioning media frenzy}

The increasing divorce rate initially became an issue in August 2020, when the long queue of Soreang Religious Courts visitors became ubiquitous on social media. ${ }^{20}$ Following this, the news on the increase in divorce rates was continuously echoed in other regencies, such as Indramayu, ${ }^{21}$ Cirebon, ${ }^{22}$ Batang, ${ }^{23}$ Jambi, ${ }^{24}$ etc. Authorities of the Religious Courts

${ }^{18}$ Cate Sumner and Timothy Lindsey, Courting Reform : Indonesia's Islamic Courts and Justice for the Poor, 1st ed, Woollahra, NSW: Lowy Institute for International Policy, 2010, http:// trove.nla.gov.au/work/38338487.

${ }^{19}$ Campbell, "An Increasing Risk of Family Violence...; Humphreys, Myint, and Zeanah, "Increased Risk for Family Violence During the COVID-19 Pandemic"; Heather Prime, Mark Wade, and Dillon T. Browne, "Risk and Resilience in Family Well-Being during the COVID-19 Pandemic”, American Psychologist, Volume 75, Number 5 (2020), 631.

${ }^{20}$ Iqbal, "Viral Antrean Mengular Pasutri Mau Cerai...

${ }^{21}$ Nurhadi Sucahyo, "Cerai Di Masa Pandemi: Ditahan PSBB, Didorong Ekonomi," 2020, https://www.voaindonesia.com/a/cerai-di-masa-pandemi-ditahan-psbb-didorongekonomi-/5578035.html.

22"Perceraian Di Cirebon Meningkat Selama Pandemi COVID-19, Dalam Sebulan Seribu Kasus," 2020, https://www.merdeka.com/peristiwa/perceraian-di-cirebon-meningkat-selamapandemi-COVID-19-dalam-sebulan-seribu-kasus.html.

23"1.119 Pasangan Di Batang Bercerai Saat Pandemi COVID-19, Ekonomi Jadi Masalah Utama," 2020, https://jateng.inews.id/berita/1119-pasangan-di-batang-bercerai-saat-pandemiCOVID-19-ekonomi-jadi-masalah-utama.

24"Diduga Karena Faktor Ekonomi, Angka Perceraian Di Jambi Meningkat Saat Pandemi," 2020, https://bekasi.pikiran-rakyat.com/nasional/pr-12687297/diduga-karena-faktorekonomi-angka-perceraian-di-jambi-meningkat-saat-pandemi. 
in those districts even gave statements regarding the increase of divorce rates by showing the number of divorce cases handled by the courts and its causes. For example, the junior clerk at the Soreang Religious Court stated that the court was overwhelmed by the high number of divorce registrations, especially in March, April, May, and June 2020. ${ }^{25}$ The media reports seem to be alarming for Indonesian society. Still, there is a need to look at the phenomenon carefully and avoid jumping to an unfounded conclusion, as it may lead to inappropriate responses.

Soon after the queue at Soreang Religious Court video went viral, the Ministry of Communication and Information's official website announced the 'disinformation' in the news on the increasing divorce rates. ${ }^{26}$ The publication cited the Director-General of the Religious Court Agency, Aco Nur, stating that the increase in the divorce rates is merely $2 \%$ of the total cases received by the Religious Courts. ${ }^{27}$ Moreover, looking at the quotes from the Religious Court authorities in the various media, it seems that they did not decisively state that there have been increases in divorce rates during the pandemic.

There were no comparisons made between the data mentioned with the previous ones. For instance, the authorities from some religious courts such as Religious Court of Makassar, Religious Court of Madiun, and the Religious Court of Klaten, mention only the number of cases registered to and resolved by the Courts. Some other news, with the headline mentioning "the increase of divorce rates," explains only the causes of the

\footnotetext{
${ }^{25}$ Iqbal, "Viral Antrean Mengular Pasutri Mau Cerai...

${ }^{26} \mathrm{PDSI}$ KOMINFO, "[DISINFORMASI] Angka Perceraian Melonjak Drastis Selama Pandemi COVID-19," Website Resmi Kementerian Komunikasi dan Informatika RI, accessed August 9, 2021, http:///content/detail/29233/disinformasi-angka-perceraian-melonjakdrastis-selama-pandemi-COVID-19/0/laporan_isu_hoaks.

${ }^{27}$ antaranews.com, "MA: Dampak Pandemi COVID-19 Pada Kasus Perceraian Tidak Signifikan," Antara News, September 3, 2020, https://www.antaranews.com/berita/1704406/ ma-dampak-pandemi-COVID-19-pada-kasus-perceraian-tidak-signifikan.
} 
divorce, mainly due to economic issues.

This explanation implies that there has been an exaggeration by the media in reporting the increase of divorce rates during the pandemic. Achmad Cholil also confirms this, a religious court judge who serves as the deputy of Purwakarta Religious Court and was previously assigned a judicial judge in the Supreme Court. To support this statement, Cholil showed data and a presentation by Nur Djanah Syaf, the Director of Religious Courts Administration of the Supreme Court, arguing against the pandemic's influence on increasing divorce rates in Indonesia. ${ }^{28}$ One of the ways to prove the media blown up phenomenon is by carefully reading the actual data published by the Religious Courts and the Supreme Courts during a specific period.

\section{Statistical data of divorce rates}

Sets of data on divorce cases handled by the Religious Courts from 2015 2020 do not show a significant increase in divorce rates from time to time. The following table shows that there have been no significant changes in the divorce rates. The data comparison between 2019 and 2020 even shows a slight decline in the divorce rates, both divorce by male repudiation and divorce by female initiation.

Table 1. Comparison of Divorce by Female Initiation and Divorce by Male Repudiation

\begin{tabular}{cccc}
\hline Year & $\begin{array}{c}\text { Divorce by Female } \\
\text { Initiation }\end{array}$ & $\begin{array}{c}\text { Divorce by Male } \\
\text { Repudiation }\end{array}$ & Total \\
\hline 2015 & 218,178 & 113,068 & 394,246 \\
2016 & 287,749 & 113,968 & 401,717 \\
\hline
\end{tabular}

${ }^{28}$ Nur Djanah Syaf, "Perceraian Di Masa Pandemi COVID-19 Dan Latar Belakang Penyebabnya.”; Interview with Ahmad Cholil, Deputy of Religious Court of Purwakarta, 9 August 2021. 


\begin{tabular}{cccc}
\hline Year & $\begin{array}{c}\text { Divorce by Female } \\
\text { Initiation }\end{array}$ & $\begin{array}{c}\text { Divorce by Male } \\
\text { Repudiation }\end{array}$ & Total \\
\hline 2017 & 301,573 & 113,937 & 415,510 \\
2018 & 325,505 & 118,853 & 444,358 \\
2019 & 355,842 & 124,776 & 480,618 \\
2020 & 346,086 & 119,442 & 465,528 \\
\hline
\end{tabular}

The 2019 and 2020 data comparison does not show any significant differences, even though 2020 was considered the first wave of the pandemic, posing uncertainty in many aspects of life. The graphs below show there had been a significant decrease in divorce case application to the Religious Courts from April to May 2020, before significantly rising again in mid June 2020.

Graph 1. Comparison of Divorce Application to the Religious Courts in January - August 2019 and January - August 202029

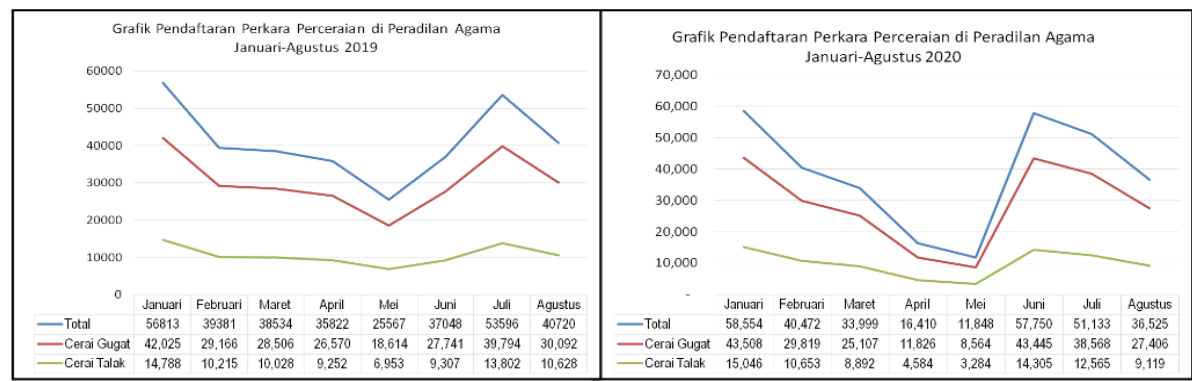

This figure is not surprising, considering that the Indonesian government determined the social mobility restriction (PSBB) to prevent the disease from spreading since April 2020 through Government Regulation No. 21 of 2020. This was applied in four provinces and

\footnotetext{
${ }^{29}$ Nur Djanah Syaf, "Perceraian Di Masa Pandemi COVID-19...
} 
regencies. ${ }^{30}$ Those provinces were Jakarta, West Sumatera, Gorontalo, and West Java. Meanwhile, the regencies included Pekanbaru, Tegal, Surabaya, Sidoarjo, and Gresik.

With PSBB policy, offices, supermarkets, banks, and other services need to limit visitors. In the 'red zone' of the pandemic, some courts closed their services, including where some of their officials were infected. ${ }^{31}$ For example, in the religious court of Cibinong, the court responded to PSBB policy by closing the case registration services and hearing. However, people could still collect the issued legal documents, such as divorce certificates. ${ }^{32}$ In Cianjur Religious Court, the court was forced to close because the COVID-19 infected some judges. ${ }^{33}$

To strengthen this argument, it is helpful to look at the data from the individual courts, the media report, especially those to have doubled in the divorce rates. The first is the Religious Courts of Soreang at Bandung Regency. According to the Annual Report of the Religious Court of Soreang 2020, there was a slight increase in the divorce cases received in 2020 compared to those in 2019, 1.25\%. In 2019, the court received

30"Penerapan PSBB Di Sejumlah Wilayah Indonesia | Indonesia Baik," accessed August 11, 2021, http://indonesiabaik.id/infografis/penerapan-psbb-di-sejumlah-wilayah-indonesia.

31"Pelayanan Di Pengadilan Agama Tutup Sementara - Radarcirebon.Com," accessed August 11, 2021, https://www.radarcirebon.com/2020/04/01/pelayanan-di-pengadilanagama-tutup-sementara/; "Hakim COVID-19, Pengadilan Agama Cianjur Tutup Tiga Hari | Republika Online," accessed August 11, 2021, https://www.republika.co.id/ berita/qmidwr459/hakim-COVID19-pengadilan-agama-cianjur-tutup-tiga-hari; "Langkah Penanganan Corona Dan Penerapan PSBB Di Lingkungan Pengadilan Agama Cibinong," accessed August 11, 2021, http://www.pa-cibinong.go.id/informasi-pengadilan/442-langkahpenanganan-corona-dan-penerapan-psbb-di-lingkungan-pengadilan-agama-cibinong; "PA Jakbar Tutup Saat PSBB, 515 Istri Gugat Cerai Suami Ketika New Normal Berlaku | Merdeka. Com," accessed August 11, 2021, https://www.merdeka.com/peristiwa/pa-jakbar-tutup-saatpsbb-515-istri-gugat-cerai-suami-ketika-new-normal-berlaku.html.

${ }^{32} \mathrm{http}: / /$ www.pa-cibinong.go.id/informasi-pengadilan/442-langkah-penanganan-coronadan-penerapan-psbb-di-lingkungan-pengadilan-agama-cibinong

33"Hakim COVID-19, Pengadilan Agama Cianjur Tutup Tiga Hari | Republika Online," accessed August 11, 2021, https://www.republika.co.id/berita/qmidwr459/hakim-COVID19. pengadilan-agama-cianjur-tutup-tiga-hari 
9,006 divorce cases, while in 2020, 9,119 cases. ${ }^{34}$ The study by Sururie and Susanto also confirms this. ${ }^{35}$ From here, it is clear that there were no significant changes from 2019 to 2020.

Similar trends also happened in other religious courts reported by the media to experience increases in the divorce rates. Here is the comparison of divorce cases submitted to the Religious Courts of Cirebon, Cilegon, Semarang, Klaten, Gresik, Parepare, Jambi, and South Jakarta. Even though South Jakarta was not in the media report, it is helpful to see the number of divorce cases in the Religious Court of South Jakarta. One of the courts usually deals with a significant number of divorce cases even before the pandemic.

The data from individual Religious Courts also show a slight decrease in the divorce cases taken to the Religious Courts from 2019-2020. In the Religious Court of Sumber in Cirebon, for example, the total divorce cases received by the court in 2019 was 8126 cases registered to the court, consisting of 2,428 divorces by male repudiation and 5,698 divorces initiated by wives. In 2020, the total divorce cases received were 7,328 , consisting of 2,151 male repudiations and 5,177 divorces initiated by wives. The data from the two periods clearly shows decreases and not increases. This happened in both types of divorce. The following table shows the comparison between divorce cases received by seven Religious Courts in 2019 and 2020.

${ }^{34}$ Pengadilan Agama Soreang, "Laporan Pelaksanaan Kegiatan Tahun 2020” (Kabupaten Bandung, 2021), 13.

${ }^{35}$ Ramdani Wahyu Sururie and Yoghi Arief Susanto, "Legal Aid Post Services at the Indonesian Religious Courts during the COVID-19 Pandemic," AHKAM : Jurnal Ilmu Syariah, Volume 20, Number 2 (December 30, 2020), http://journal.uinjkt.ac.id/index. $\mathrm{php/ahkam/article/view/17469.}$ 
Table 2. Divorce Cases Received in 2019 and 2020

\begin{tabular}{|c|c|c|}
\hline \multirow{2}{*}{ Religious Court } & \multicolumn{2}{|c|}{ Total Divorce Cases } \\
\hline & 2019 & 2020 \\
\hline Sumber (Cirebon) ${ }^{36}$ & 8126 & 7328 \\
\hline Cilegon $^{37}$ & 833 & 828 \\
\hline Gresik $^{38}$ & 2283 & 2431 \\
\hline Parepare $^{39}$ & 542 & 437 \\
\hline $\mathrm{Jambi}^{40}$ & 1108 & 943 \\
\hline South Jakarta ${ }^{41}$ & 4809 & 4175 \\
\hline Soreang (Bandung Regency) & 9,006 & 9,119 \\
\hline
\end{tabular}

${ }^{36}$ Pengadilan Agama Sumber - Cirebon, "Laporan Tahunan 2020" (Cirebon: Pengadilan Agama Sumber Kelas IA, 2021), https://drive.google.com/file/d/1j4ulXhLw1R_ XXBEnwQBYV3vs-oz7605L/view?usp=sharing\&usp=embed_facebook; Pengadilan Agama Sumber, "Laporan Tahunan Pengadilan Agama Sumber 2019" (Cirebon: Pengadilan Agama Kelas IA Sumber), accessed August 12, 2021, https://drive.google.com/file/d/1gR0jj6essQXTI52E515FjmfHL7wMMRo/view?usp=sharing\&usp=embed_facebook.

${ }^{37}$ Pengadilan Agama Cilegon, "Laporan Pelaksanaan Kegiatan Tahun 2020" (Cilegon: Pengadilan Agama Cilegon Kelas II), accessed August 12, 2021, https://drive.google.com/ file/d/1qf22cZsiWxTQiXoX9EXBJTcvqsXLUMEi/view?usp=sharing\&usp=embed_facebook; Pengadilan Agama Cilegon, "Laporan Kegiatan 2019" (Cilegon, 2020), https://drive.google. com/file/d/1OaXnH_nCT_OrlyswF5KXjUCL8m4zw8N8/view?usp=sharing\&usp=embed_ facebook.

${ }^{38}$ Pengadilan Agama Gresik, "Laporan Pelaksanaan Kegiatan 2019” (Gresik: Pengadilan Agama Gresik, 2019), https://www.pa-gresik.go.id/phocadownload/LapTahunan/ laporan\%20tahunan\%202019\%20lengkap.pdf; Pengadilan Agama Gresik, "Laporan Tahunan Tahun 2020" (Gresik: Pengadilan Agama Gresik, 2021).

${ }^{39}$ Pengadilan Agama Parepare, "Laporan Pelaksanaan Kegiatan Tahun 2019" (Parepare: Pengadilan Agama Parepare Kelas IB, 2020), https://drive.google.com/file/d/1Y7LoQIzezj2sioxrDYkQRK69m-_PTUS/view?usp=drive_open\&usp=embed_facebook; Pengadilan Agama Parepare, "Laporan Pelaksaan Kegiatan 2020" (Parepare: Pengadilan Agama Parepare Kelas IB, 2021).

${ }^{40}$ Pengadilan Agama Jambi, "Laporan Pelaksanaan Kegiatan Tahun 2019” (Jambi: Pengadilan Agama Jambi, 2020); Pengadilan Agama Jambi, "Laporan Pelaksanaan Kegiatan Tahun 2020" (Jambi: Pengadilan Agam Jambi, 2021), https://drive.google.com/ file/d/14egJuCjkGI8bZAsddVDJ_FmkxZyPIZ1S/view?usp=sharing\&usp=embed_facebook.

${ }^{41}$ Pengadilan Agama Jakarta Selatan, "Laporan Pelaksaan Kegiatan Tahun 2019” (Jakarta: Pengadilan Agama Jakarta Selatan, 2020), https://drive.google.com/file/d/1RKxrfYSAO- 
The above data implies that the uproar in the media is unproven. Even some of the Religious Courts mentioned in the media experienced a decrease in divorce case registration, such as Sumber, Jambi, Cilegon, and Parepare. Even though the Religious Court of Gresik witnessed the increase in the number of divorce cases registered, the number is not significant, only $6 \%$.

\section{Factor behind divorce application crowding}

The question is: What caused the crowding in some Religious Courts, which attracted media attention? Has the media lied to the public? The answer to the second question is no. The crowding in the Soreang Religious Court was real. The number mentioned in the news was confirmed. However, an explanation is needed to see what was happened. Moreover, few month increases do not always reflect the whole picture of divorce rates in Indonesia.

As explained above, the PSBB policy upheld by the Indonesian government forced many offices to stop the operation, including the courts. In Soreang, the crowd and long queues were caused by two factors. First, the closing of the court during PSBB prevented people from coming to the courts. They needed to wait until the court officially re-opened the services. Soon after the court was opened, the outburst of visitors occurred. Second, the 'New Normal' policy requires maintaining at least one-meter distance from one person to another and avoiding close contact between people. This, in turn, makes offices limit the number of visitors, especially indoors. The government has issued regulations to limit visitors in offices, courts, supermarkets, traditional markets, cafés and restaurants, etc. The

\footnotetext{
b0X0d5pMzSx2iD6FycOgyZ/view?usp=sharing\&usp=embed_facebook; Pengadilan Agama Jakarta Selatan, "Laporan Pelaksaan Kegiatan 2020" (Jakarta: Pengadilan Agama Jakarta Selatan, 2021), https://drive.google.com/file/d/1MjKlThwlgRP0OcWj29LrhwhRrKe1VV $7 \mathrm{f} /$ view? usp=sharing\&usp=embed_facebook.
} 
Ministry of Health issued the regulations, the Ministry of Trade (Minister of Trade Circular No. 12 of 2020), and even local governments (The Mayor of Depok Regulation No. 59 of 2020; The Regulation of Jakarta Governor No. 33 of 2020; The Regulation of Jakarta Governor No. 88 of 2020 , etc.). The numbers of regulations are meant to adjust to the need of different places and situations.

This explanation is in line with the argument of the Religious Court agency of the Supreme Court in responding to the news. It is stated that the 'New Normal' regulation with the requirement of social distancing has significantly influenced the situation in the Religious Courts. Chairs provided for the visitors have been set according to the required distance and the number of visitors allowed in the room. As a consequence, many visitors had no other choice but to queue outside the courts. With such requirements, the courts have equipped themselves with the necessary facilities. This is reflected in the 2020 annual report of every Religious court. The increase in the news reported divorce rate was actual, but only for specific months, as shown by the above figure.

\section{Factors causing divorce}

Apart from informing the divorce rates, the media attempted to dig up the information about the cause of divorce. Several media reports mentioned the economy as the cause of the divorce. There are at least three common causes of divorce resolved by the Religious Courts: economic issues, continuous quarrels, and one couple leaving the other.

Questioned by the media, Mahdi Syam, the Public Relations Officer at Cilegon Religious Courts, stated that economic issues caused most divorce cases taken to court. The same statement was also made by Rusdi, a clerk at Religious Court of Jambi, and Muhammad Camuda, Deputy of Semarang Religious Courts. Economic issues-as the main cause of 
divorce during the pandemic-became headlines in the media. In Batang, for example, the headline mentioned: "1,119 Couples in Batang Divorced during the Pandemic, Economic Issues Became the Main Problem.” In Jambi, Pikiran Rakyat News mentioned: "Allegedly Caused by Economic Factors, Divorce Rates in Jambi Have Increased during the Pandemic."

Economic distress has been one of the significant effects of the pandemic. Many people have lost their jobs. It is quite reasonable if economic issues become the cause of divorce during the pandemic. However, looking at previous data before the pandemic, economic distress is the most common cause of divorce. The following is the comparison between 2019 and 2020 on the cause of divorce from the Supreme Court:

Table 3. Factors Causing Divorce

\begin{tabular}{lll}
\hline \multicolumn{1}{c}{ Factors Causing Divorce } & 2019 & 2020 \\
\hline Continuous quarrel & $55 \%$ & $58 \%$ \\
Economy & $27 \%$ & $26 \%$ \\
One spouse leaving the other & $14 \%$ & $12 \%$ \\
Domestic violence & $1.3 \%$ & $1.2 \%$ \\
Liquor abuse & $0.5 \%$ & $0.4 \%$ \\
Apostasy & $0.3 \%$ & $0.3 \%$ \\
Polygamy & $0.2 \%$ & $0.2 \%$ \\
Imprisoned & $0.2 \%$ & $0.2 \%$ \\
Gambling & $0.2 \%$ & $0.2 \%$ \\
Adultery & $0.1 \%$ & $0.1 \%$ \\
\hline
\end{tabular}

From the above data, it can be seen that the economic issue is a common cause of divorce. The percentages come second after a continuous quarrel with a significant discrepancy. This reflects that the economic issue has not been proven to be the main factor causing divorce. The Religious Court 
Agency also used the above data to argue against increasing divorce rates during the pandemic. This paper would argue that, more or less, the social assistance programs for households upheld by the government play a role in stabilizing the households' economic conditions.

\section{Has the Covid-19 pandemic caused the increase in divorce rates?}

The above explanation implies that the influence of the COVID-19 pandemic on divorce rates has not yet been proven. The data sets taken from the Supreme Court and various courts have not shown the significant increase of divorce cases submitted to the Religious Courts during the pandemic. However, the discussion cannot stop here. There is a need to consider the long term impact of the pandemic on households. Moreover, the increasing number of violence reports is alarming for the government and society to consider.

The impact of the COVID-19 pandemic on households is real. Psychology, economy, and children upbringing are among them. ${ }^{42}$ However, even though family stability has been in a vulnerable situation during the pandemic, it seems that divorce has not been the choice taken in Indonesia. Media exaggeration of the rising divorce rate in Indonesia as the impact of the COVID-19 pandemic has not been confirmed. The delay in court administration as the cause of the social mobilization restriction and social distancing is the main cause of the booming of divorce cases in certain months. These few months' phenomena have not defined the entire divorce pattern in Indonesia amidst the pandemic.

The backlog in divorce application can be overcome by the E-ourt system developed by the Supreme Court. The E-Court system was launched for the first time in 2018 with the Supreme Court Regulation No. 3 of 2018

\footnotetext{
${ }^{42}$ Amakiri et al., "Psychological Effect of Pandemic COVID-19...; Humphreys, Myint, and Zeanah, "Increased Risk for Family Violence During the COVID-19 Pandemic...; Ahmed, Buheji, and Fardan, "Re-Emphasising the Future Family Role...
} 
on the Guidance for Electronic Case Administration in Courts.However, Ahmad Cholil and Yayuk Afianah stated that the program had not been supported by the readiness of the court users to operate it. The current uneasy situation can be a perfect moment for the Supreme Court, in general, to introduce the E-Court system to the broader public.

Regarding the economic factor as the main cause of divorce, the above analysis shows that it is also unproven. The data shows that the economy has been consistent as the second common factor causing divorce in Indonesia. This is also confirmed by Yayuk Afianah, a Religious Court judge of South Tangerang, that even during the pandemic, divorce caused by economic factors has not exceeded divorce caused by spouse quarrels. ${ }^{43}$ Moreover, the Indonesian government has several policies and programs to help vulnerable groups during the pandemic, responding to the economic difficulties. Among the programs rolled out by the government are 1) electricity bill discount for households with $400 \mathrm{VA}$ and $950 \mathrm{VA}$ electrical power; 2) non-cash food assistance (Bantuan Pangan Non-Tunai); 3) Cash social assistance, and 4) staple food social assistance (Bantuan Sembako Sosial). The government allocated an IDR 203.9 Trillion budget for all programs, stipulated in Presidential Regulation No. 7 of $2020 .{ }^{44}$ In addition, under the supervision of the Ministry of Education, the government distributes pre-paid mobile phone credit to help households access the Internet with homeschooling during the pandemic. ${ }^{45}$ The aids distributed by the government, more or less, have played a significant role

\footnotetext{
${ }^{43}$ Interview with Yayuk Afianah, a judge at Religious Court of South Tangerang, 9 August 2021.

${ }^{44}$ UNICEF et al., "Analysis of the Social and Economic Impacts of COVID-19 on Households and Strategic Policy Recommendation for Indonesia."

45“Kemendikbud Resmikan Kebijakan Bantuan Kuota Data Internet 2020," Kementerian Pendidikan, Kebudayaan, Riset, dan Teknologi, September 25, 2020, https://www. kemdikbud.go.id/main/blog/2020/09/kemendikbud-resmikan-kebijakan-bantuan-kuotadata-internet-2020.
} 
in maintaining household resilience.

Another emerging notion is related to the high number of divorce applications filed by wives. In media interviews, some Religious Court authorities revealed that most cases taken to the courts during the pandemic had been divorce initiated by wives. This is true. The table below shows that in 2020 more divorce initiations were made by the wives.

Table 4. Comparison of Divorce by Female Initiation and Divorce by Male Repudiation

\begin{tabular}{lcccc}
\hline \multirow{2}{*}{ Religious Court } & \multicolumn{2}{c}{2019} & \multicolumn{2}{c}{2020} \\
\cline { 2 - 5 } & $\begin{array}{c}\text { Divorce } \\
\text { by Male } \\
\text { Repudiation }\end{array}$ & $\begin{array}{c}\text { Divorce } \\
\text { Initiated } \\
\text { by Wife }\end{array}$ & $\begin{array}{c}\text { Divorce } \\
\text { by Male } \\
\text { Repudiation }\end{array}$ & $\begin{array}{c}\text { Divorce } \\
\text { Initiated by } \\
\text { Wife }\end{array}$ \\
\hline Sumber (Cirebon) $^{46}$ & 2428 & 5698 & 2151 & 2428 \\
Cilegon $^{47}$ & 189 & 644 & 230 & 588 \\
Gresik $^{48}$ & 603 & 1680 & 683 & 1748 \\
Parepare $^{49}$ & 103 & 439 & 180 & 357 \\
Jambi $^{50}$ & 253 & 856 & 216 & 727 \\
South Jakarta $^{51}$ & 1194 & 3615 & 1108 & 3067 \\
\hline
\end{tabular}

However, this is not new. Compared to the data in 2019, before the pandemic, the figure shows the same. This is a common phenomenon,

\footnotetext{
${ }^{46}$ Pengadilan Agama Sumber - Cirebon, "Laporan Tahunan 2020"; Pengadilan Agama Sumber, "Laporan Tahunan Pengadilan Agama Sumber 2019."

${ }^{47}$ Pengadilan Agama Cilegon, "Laporan Pelaksanaan Kegiatan Tahun 2020"; Pengadilan Agama Cilegon, "Laporan Kegiatan 2019."

${ }^{48}$ Pengadilan Agama Gresik, "Laporan Pelaksanaan Kegiatan 2019”; Pengadilan Agama Gresik, "Laporan Tahunan Tahun 2020.”

${ }^{49}$ Pengadilan Agama Parepare, "Laporan Pelaksanaan Kegiatan Tahun 2019”; Pengadilan Agama Parepare, "Laporan Pelaksaan Kegiatan 2020.”

${ }^{50}$ Pengadilan Agama Jambi, "Laporan Pelaksanaan Kegiatan Tahun 2019"; Pengadilan Agama Jambi, "Laporan Pelaksanaan Kegiatan Tahun 2020.”

${ }^{51}$ Pengadilan Agama Jakarta Selatan, "Laporan Pelaksaan Kegiatan Tahun 2019"; Pengadilan Agama Jakarta Selatan, "Laporan Pelaksaan Kegiatan 2020.”
} 
especially after the legal reform made by the Indonesian judiciary. With the legal reform, the Indonesian judiciaries maintain their commitments to uphold simple, fast, and low-cost processes. The Religious Courts have become the courts delivering justice to the marginalized and vulnerable groups, especially women and the economically disadvantaged.52 Apart from that, many programs have been organized to increase access to justice, involving courts and other offices, such as Civil Registry Office, Religious Affairs Office, etc. ${ }^{53}$

Regarding the increasing violence reports, the question is why the increasing violence reports have not led to the increasing divorce rates. The first explanation would be that the number has resulted from the successful outreach toward violence victims. ${ }^{54}$ In the case of Indonesia, among the actors that play a significant role in reaching the violence victims is KOMNAS Perempuan. This institution has also produced reliable data regarding the issue of violence in Indonesia. Despite the obstacles caused by the pandemic, the reports of violence received by KOMNAS Perempuan have increased. It is also important to note that there may be a high number of unreported cases.

The second explanation for the unparalleled data of the domestic violence and divorce rates is that the trend shows that violence has not been the primary cause of divorce in Indonesia. The above data from the Supreme Court show that violence is the fourth cause of divorce. Nevertheless, the data revealed by KOMNAS Perempuan is an alarming situation. There is a need to increase the outreach of violence victims by

\footnotetext{
${ }^{52}$ Sumner and Lindsey, Courting Reform.

53“PA Jakbar Tutup Saat PSBB, 515 Istri Gugat Cerai Suami Ketika New Normal Berlaku | Merdeka.Com"; "Hakim COVID-19, Pengadilan Agama Cianjur Tutup Tiga Hari | Republika Online"; "Langkah Penanganan Corona Dan Penerapan PSBB Di Lingkungan Pengadilan Agama Cibinong"; "Pelayanan Di Pengadilan Agama Tutup Sementara - Radarcirebon.Com."

${ }^{54} \mathrm{~K}$. J. Wilson, When Violence Begins at Home: A Comprehensive Guide to Understanding and Ending Domestic Abuse, Hunter House, 2005.
} 
the state authorities, as the pandemic leading to a more complex situation for many households.

\section{Conclusion}

This study finds out that the one-year period (2020) of the COVID-19 pandemic has not influenced the rates of divorce cases submitted to the court. Social mobility restrictions are among the causes of the crowding of divorce applicants. The economic factor that is allegedly the leading cause of divorce during the pandemic has not been proven, as the number of divorces caused by this factor has remained stable from year to year. Also, the trend that most divorce initiated by women has been common with easier access to justice. Furthermore, the E-Court system, which is supposed to be the solution to the very limited access to the courts, has not been widely accessible due to the limited knowledge of the litigants in using the system.

This study implies that the current COVID-19 pandemic has little impact on divorce dynamics despite its significant influence on households' economic instability and the increasing of domestic violence cases. With a more careful response to the media report, the authorities will be able to address the real issues faced by many households and the judiciary. Further studies are needed to explain the long-term influence of the pandemic on the divorce dynamics and the reason for the disproportionate rates of divorce vis-à-vis domestic violence cases.

\section{Bibliografi}

Afifah, Qisti Aufa, "Analysis of the Impact of the Covid-19 Pandemic on Family Harmony: Case Studies on Family with and without People with Special Needs", Indonesian Journal of Community and Special Needs Education, Volume 1, Number 2 (2021): 87-92.

Ahmed, Dunya, Mohamed Buheji, and S. Merza Fardan, "Re-Emphasizing the Future Family Role in 'Care Economy' as a Result of Covid-19 Pandemic 
Spillovers", American Journal of Economics, Volume 10, Number 6 (2020): 332-38.

Amakiri, Paschal Chiedozie, Chidimma Florence Chude, S. U. Oradiegwu, I. Primanik, Kennedy Chijioke Anoka, and Q. A. Ezeoke, "Psychological Effect of Pandemic COVID-19 on Families of Health Care Professionals", British Journal of Psychology Research, Volume 8, Number 2 (2020): 1-7.

Campbell, Andrew M., "An Increasing Risk of Family Violence during the Covid-19 Pandemic: Strengthening Community Collaborations to Save Lives," Forensic Science International: Reports, Volume 2 (2020): 100089. https://doi.org/10.1016/j.fsir.2020.100089.

Fallesen, Peter, "Decline in Rate of Divorce and Separation Filings in Denmark in 2020 Compared with Previous Years", Socius, Volume 7 (2021): 23780231211009990.

Humphreys, Kathryn L., Myo Thwin Myint, and Charles H. Zeanah, "Increased Risk for Family Violence During the COVID-19 Pandemic", Pediatrics, Volume 146, Number 1 (2020). https://doi.org/10.1542/peds.2020-0982. Iqbal, Muhammad, "Viral Antrean Mengular Pasutri Mau Cerai di PA Bandung, Apa Benar?", detiknews, August 24, 2020. https://news.detik.com/beritajawa-barat/d-5144552/viral-antrean-mengular-pasutri-mau-cerai-di-pabandung-apa-benar.

Manning, Wendy D., and Krista K. Payne, "Marriage and Divorce Decline During the COVID-19 Pandemic: A Case Study of Five States", Socius, Volume 7 (2021): 23780231211006976.

Pengadilan Agama Gresik. Laporan Tahunan Tahun 2020. Gresik: Pengadilan Agama Gresik, 2021.

Pengadilan Agama Jakarta Selatan. Laporan Pelaksaan Kegiatan 2020. Jakarta: Pengadilan Agama Jakarta Selatan, 2021. https://drive. google.com/file/d/1MjKlThwlgRP0OcWj29LrhwhRrKe1VV7f/ view?usp=sharing\&usp=embed_facebook.

Pengadilan Agama Jakarta Selatan. Laporan Pelaksaan Kegiatan Tahun 2019. Jakarta: Pengadilan Agama Jakarta Selatan, 2020. https:// drive.google.com/file/d/1RKxrfYSAO-b0X0d5pMzSx2iD6Fyc0gyZ/ view?usp=sharing\&usp=embed_facebook.

Pengadilan Agama Jambi. Laporan Pelaksanaan Kegiatan Tahun 2019. Jambi: Pengadilan Agama Jambi, 2020.

Pengadilan Agama Jambi. Laporan Pelaksanaan Kegiatan Tahun 2020. Jambi: Pengadilan Agam Jambi, 2021. https://drive.google. 
com/file/d/14egJuCjkGI8bZAsddVDJ_FmkxZyPIZ1S/ view?usp=sharing\&usp=embed_facebook.

Pengadilan Agama Parepare. Laporan Pelaksaan Kegiatan 2020. Parepare:

Pengadilan Agama Parepare Kelas IB, 2021.

Pengadilan Agama Parepare. Laporan Pelaksanaan Kegiatan Tahun 2019. Parepare:

Pengadilan Agama Parepare Kelas IB, 2020. https://drive.google.com/

file/d/1Y7LoQIzezj2si-oxrDYkQRK69m-_PTUS/view?usp=drive_ open\&usp=embed_facebook.

Pengadilan Agama Soreang. Laporan Pelaksanaan Kegiatan Tahun 2020. Bandung, Pengadilan Agama Soreang, 2021.

Pengadilan Agama Sumber. Laporan Tahunan Pengadilan Agama Sumber 2019. Cirebon: Pengadilan Agama Kelas IA Sumber, 2019. Accessed August 12, 2021. https://drive.google.com/file/d/1gR0jj6essQXTI52E515FjmfHL7wMMRo/view?usp=sharing\& usp=embed_facebook.

Pengadilan Agama Sumber. Laporan Tahunan 2020. Cirebon: Pengadilan Agama Sumber Kelas IA, 2021. https://drive.google.com/file/d/1j4ulXhLw1R_ XXBEnwQBYV3vs-oz7605L/view?usp=sharing\&usp=embed_facebook.

Prime, Heather, Mark Wade, and Dillon T. Browne, "Risk and Resilience in Family Well-Being during the COVID-19 Pandemic", American Psychologist, Volume 75, Number 5 (2020): 631-643.

Ramadhani, Salsabila Rizky, and Nunung Nurwati, "Dampak Pandemi COVID-19 Terhadap Angka Perceraian”, Jurnal Penelitian dan Pengabdian Kepada Masyarakat, Volume 2, no. 1 (2021): 88-94. https://doi.org/10.24198/ jppm.v2i1.33441.

Sucahyo, Nurhadi, "Cerai Di Masa Pandemi: Ditahan PSBB, Didorong Ekonomi," 2020. https://www.voaindonesia.com/a/cerai-di-masa-pandemiditahan-psbb-didorong-ekonomi-/5578035.html.

Sumner, Cate, and Timothy Lindsey. Courting Reform: Indonesia's Islamic Courts and Justice for the Poor. 1st ed. Woollahra, N.S.W.: Lowy Institute for International Policy, 2010. http://trove.nla.gov.au/work/38338487.

Sururie, Ramdani Wahyu, and Yoghi Arief Susanto, "Legal Aid Post Services at the Indonesian Religious Courts during the COVID-19 Pandemic", AHKAM: Jurnal Ilmu Syariah, Volume 20, Number 2 (2020). http://journal.uinjkt. ac.id/index.php/ahkam/article/view/17469.

Syaf, Nur Djanah, "Perceraian Di Masa Pandemi COVID-19 Dan Latar Belakang Penyebabnya”, Webinar BP-4 Kementerian Agama RI, September 8, 2020. Ulfa, Mawaddatul, and Mahlil Bunaiya, "The Effect of COVID-19 on the High 
Divorce Rate in Kabupaten Lima Puluh Kota”, HUNAFA: Jurnal Studia Islamika, Volume 18, Number 1 (2021): 114-137. https://doi.org/10.24239/ jsi.v18i1.617.114-137.

UNICEF, UNDP, Prospera, and SMERU. Analysis of the Social and Economic Impacts of COVID-19 on Households and Strategic Policy Recommendation for Indonesia. Jakarta: United Nation Children's Fund, 2021. https://www. id.undp.org/content/indonesia/en/home/library/HH-Socio-EconomicReport.html.

Wilson, K. J. When Violence Begins at Home: A Comprehensive Guide to Understanding and Ending Domestic Abuse. Hunter House, 2005.

Zhang, Hongwei, "The Influence of the Ongoing COVID-19 Pandemic on Family Violence in China”, Journal of Family Violence, (2020): 1-11.

\section{Internet}

Antaranews.com. "MA: Dampak Pandemi COVID-19 Pada Kasus Perceraian Tidak Signifikan.” Antara News, September 3, 2020. https://www. antaranews.com/berita/1704406/ma-dampak-pandemi-covid-19-pada-kasusperceraian-tidak-signifikan.

"Diduga Karena Faktor Ekonomi, Angka Perceraian Di Jambi Meningkat Saat Pandemi," 2020. https://bekasi.pikiran-rakyat.com/nasional/pr-12687297/ diduga-karena-faktor-ekonomi-angka-perceraian-di-jambi-meningkat-saatpandemi.

"Hakim Covid-19, Pengadilan Agama Cianjur Tutup Tiga Hari | Republika Online." Accessed August 11, 2021. https://www.republika.co.id/berita/ qmidwr459/hakim-covid19-pengadilan-agama-cianjur-tutup-tiga-hari.

"Indonesia: WHO Coronavirus Disease (COVID-19) Dashboard with Vaccination Data." Accessed 19 August 2021. https://covid19.who.int.

"Januari Hingga Juni PTA Bandar Lampung Catat 6000 Kasus Perceraian," 2020. https://www.kompas.tv/article/96465/januari-hingga-juni-pta-bandarlampung-catat-6000-kasus-perceraian.

"Kasus Perceraian Di Gresik Meningkat Selama Pandemi Covid-19 Halaman All - Kompas.Com." Accessed August 16, 2021. https://regional.kompas. com/read/2021/06/29/161842978/kasus-perceraian-di-gresik-meningkatselama-pandemi-covid-19? page $=$ all.

Kementerian Pendidikan, Kebudayaan, Riset, dan Teknologi, "Kemendikbud Resmikan Kebijakan Bantuan Kuota Data Internet 2020,” September 25, 
2020. https://www.kemdikbud.go.id/main/blog/2020/09/kemendikbudresmikan-kebijakan-bantuan-kuota-data-internet-2020.

KOMINFO, PDSI. "[DISINFORMASI] Angka Perceraian Melonjak Drastis Selama Pandemi Covid-19." Website Resmi Kementerian Komunikasi dan Informatika RI. Accessed August 9, 2021. http:///content/detail/29233/ disinformasi-angka-perceraian-melonjak-drastis-selama-pandemi-covid-19/0/ laporan_isu_hoaks.

Komnas Perempuan. "Siaran Pers." Komnas Perempuan | Komisi Nasional Anti Kekerasan Terhadap Perempuan, March 5, 2021. https://komnasperempuan. go.id/siaran-pers-detail/catahu-2020-komnas-perempuan-lembar-fakta-danpoin-kunci-5-maret-2021.

kompas.com. "Tingkat Perceraian Di Kabupaten Bandung Melonjak Di Masa Pandemi Covid-19," 2020. https://regional.kompas.com/ $\mathrm{read} / 2020 / 08 / 24 / 13582481 /$ tingkat-perceraian-di-kabupaten-bandungmelonjak-di-masa-pandemi-covid-19.

"Langkah Penanganan Corona Dan Penerapan PSBB Di Lingkungan Pengadilan Agama Cibinong." Accessed August 11, 2021. http://www.pa-cibinong. go.id/informasi-pengadilan/442-langkah-penanganan-corona-danpenerapan-psbb-di-lingkungan-pengadilan-agama-cibinong.

"PA Jakbar Tutup Saat PSBB, 515 Istri Gugat Cerai Suami Ketika New Normal Berlaku | Merdeka.Com." Accessed August 11, 2021. https://www.merdeka. $\mathrm{com} /$ peristiwa/pa-jakbar-tutup-saat-psbb-515-istri-gugat-cerai-suami-ketikanew-normal-berlaku.html.

Pasangan Di Batang Bercerai Saat Pandemi Covid-19, Ekonomi Jadi Masalah Utama," 2020. https://jateng.inews.id/berita/1119-pasangan-di-batangbercerai-saat-pandemi-covid-19-ekonomi-jadi-masalah-utama.

"Pelayanan Di Pengadilan Agama Tutup Sementara - Radarcirebon.Com." Accessed August 11, 2021. https://www.radarcirebon.com/2020/04/01/ pelayanan-di-pengadilan-agama-tutup-sementara/.

"Penerapan PSBB Di Sejumlah Wilayah Indonesia | Indonesia Baik.” Accessed August 11, 2021. http://indonesiabaik.id/infografis/penerapan-psbb-disejumlah-wilayah-indonesia.

Pengadilan Agama Cilegon, "Laporan Kegiatan 2019." Cilegon, 2020. https:// drive.google.com/file/d/1OaXnH_nCT_OrlyswF5KXjUCL8m4zw8N8/ view?usp=sharing\& usp=embed_facebook.

Pengadilan Agama Cilegon, "Laporan Pelaksanaan Kegiatan Tahun 2020." Cilegon: Pengadilan Agama Cilegon Kelas II. Accessed August 12, 2021. 
https://drive.google.com/file/d/1qf22cZsiWxTQiXoX9EXBJTcrqsXLUM $\mathrm{Ei} /$ view?usp=sharing\&usp=embed_facebook.

Pengadilan Agama Gresik, "Laporan Pelaksanaan Kegiatan 2019." Gresik: Pengadilan Agama Gresik, 2019. https://www.pa-gresik.go.id/ phocadownload/LapTahunan/laporan\%20tahunan\%202019\%20lengkap. pdf.

"Perceraian Di Cirebon Meningkat Selama Pandemi Covid-19, Dalam Sebulan Seribu Kasus," 2020. https://www.merdeka.com/peristiwa/perceraian-dicirebon-meningkat-selama-pandemi-covid-19-dalam-sebulan-seribu-kasus. html.

"Perceraian Di Semarang Naik 3 Kali Lipat Selama Wabah Corona," 2020. https://www.cnnindonesia.com/nasional/20200624103600-20-516800/ perceraian-di-semarang-naik-3-kali-lipat-selama-wabah-corona.

"Selama Pandemi Corona, Kasus Perceraian Melonjak," 2020. https://fin. co.id/2020/07/11/selama-pandemi-corona-kasus-perceraian-melonjak/.

"Selama Pandemi Covid-19, Ada 1.161 Janda Baru Di Klaten," 2020. https:// www.solopos.com/selama-pandemi-covid-19-ada-1-161-janda-baru-diklaten-1098066.

"WHO Coronavirus (COVID-19) Dashboard." Accessed 19 August 2021. https:// covid19.who.int. 
